\title{
Developmental Effects of Additional Ultraviolet a Radiation, Growth Regulators and Tyrosine in Alternanthera brasiliana (L.) Kuntze Cultured in vitro
}

\author{
Nina Cláudia Barboza Silva ${ }^{1 *}$, Andrea Furtado Macedo ${ }^{1}$, Celso Luís Salgueiro Lage ${ }^{1}$, \\ Maria Apparecida Esquibel ${ }^{1}$ and Alice Sato ${ }^{2}$ \\ ${ }^{1}$ Laboratório de Fisiologia Vegetal; Instituto de Biofísica Carlos Chagas Filho; Universidade Federal do Rio de \\ Janeiro; ninacbs@biof.ufrj.br; Rio de Janeiro - RJ - Brasil. ${ }^{2}$ Departamento de Ciências Naturais; Centro de \\ Ciências Biológicas e da Saúde; Universidade Federal do Estado do Rio de Janeiro; Rio de Janeiro - RJ - Brasil
}

\begin{abstract}
Tissue cultures of Alternanthera brasiliana (L.) Kuntze were treated with different growth regulators (Kinetin and 2,4-D), tyrosine and Ultraviolet A radiation (UV-A; 320 - $400 \mathrm{~nm})$ to investigate their effects on development and pigment production. Nodal segments of plantlets grown from seeds were inoculated in all tested media and different light conditions. After eight weeks, this material was used to evaluate biomass, chlorophyll and betacyanin production. The Murashige and Skoog $(M S)+$ kinetin medium resulted in development of approximately four shoots/explant. This medium plus white light was the best combination for micropropagation with the highest rooting percentage and betacyanin production. Plantlets grown under UV-A illumination reduced biomass accumulation and worse Chlorophyll a / Chlorophyll b ratio. Addition of 2,4-D resulted in inhibition of pigment production and growth of plantlets.
\end{abstract}

Key words: Betacyanin, Chlorophyll, Morphogenesis, Tissue Culture

\section{INTRODUCTION}

The medicinal plant Alternanthera brasiliana (L.) Kuntze is an annual herbal plant belonging to Amaranthaceae family (Order Centrospermae), commonly known as "terramicina" or "penicilina" in some regions of Rio de Janeiro State. The red pigment extracted from its leaves is used to treat skin injuries. In vitro antiviral activity against Human Immunodeficiency (HIV) (Si-Man et al.,1988) and Herpes Simplex Viruses (HSV) (Lagrota et al., 1994) has been demonstrated for Alternanthera spp extracts. Methanolic and hydro alcoholic extracts obtained from A. brasiliana in vitro cultivated plantlets (Souza et al., 1998) and callus (Macedo et al., 1999) presented analgesic properties in recent findings with different in vivo pharmacological models.

The majority of families from Centrospermae Order produce betacyanins, pigments from the class of betalains. These pigments confer the red violet color to stems and leaves and, less frequently, to flowers and fruits (Mabry, 1980). Insect injuries or nutritional deficiency stimulate betacyanin production, but its functions in plants are poorly understood, except in flowers where it

*Author for correspondence 
appears to attract pollinator's insects (Piattelli and Minale, 1964). Betacyanin production was increased in Chenopodium album cell cultures when they were grown under ultraviolet light (UV) or other UV-emitting sources (Rudat and Göring, 1995).

Little is known about the effects of UV-A on plants when compared to those of UV-B. Its photoprotective function has been highlighted in terms of stimulation of DNA repair and moderating UV-B negative physiological effects in tissue cultures (Quesada et al., 1995). However, plants are predominantly exposed to UV-A radiation than to other UV wavelengths since UV-A cannot be attenuated by the ozone layer (Holm-Hansen et al., 1993).

The aim of present work was to study the effects of different growth regulators and UV-A light on morphogenesis and pigment production in in vitro cultures of A. brasiliana.

\section{MATERIAL AND METHODS}

\section{Establishment of in vitro culture}

The cultures were initiated from A. brasiliana (L.) Kuntze seeds from matrix plants growing in the gardens of Universidade Federal do Rio de Janeiro - CCS and identified by the Systematic Department of Botanic Garden of Rio de Janeiro where a voucher is registered under number RB 310.939 A.F. Macedo 01.

Surface sterilization of seeds were done by successive immersions in commercial detergent solution (30 $\mathrm{min}), 70 \%$ (v/v) ethanol (2 min), 50\% (v/v) commercial bleach solution (20 min), always intercepted with immersions in sterile distilled water (3 times/ $5 \mathrm{~min}$ ). After that, they were aseptically inoculated in solid medium (basic composition according to Murashige and Skoog, 1962), supplemented with 30 g. $\mathrm{L}^{-1}$ sucrose, 1.48 $\mu \mathrm{M}$ thiamine- $\mathrm{HCl}, 2.43 \mu \mathrm{M}$ pyridoxin, $4.1 \mu \mathrm{M}$ nicotinic acid and $0.6 \mathrm{mM}$ myo-inositol. The $\mathrm{pH}$ was adjusted to $5.8 \pm 0.1$ before addition of 8.0 g. $\mathrm{L}^{-1}$ agar, and then all media were sterilized by autoclaving $\left(120^{\circ} \mathrm{C}\right.$ and $1.1 \mathrm{Kgf} . \mathrm{cm}^{-2}$ for $\left.15 \mathrm{~min}\right)$. The material was kept under white light illumination (Sylvania fluorescent tubs), at a fluency of $1.6 \mathrm{~W} . \mathrm{m}^{-2}$, daily photoperiod of 16 hours at $25 \pm 1{ }^{\circ} \mathrm{C}$. The germinated plantlets were subcultured every 45 days and maintained under the conditions described above. Plantlets at fourth subcultivation were used as explants donors for tests with growth regulators and different light conditions.

\section{Growth under different light conditions and regulators}

Groups of 25 nodal segments, with two axillary buds without leaves or petioles, from Murashige and Skoog basic medium (MS) cultured plantlets, were introduced in six different culture media: (1) MS; (2) MS $+2 \mu \mathrm{M} 2,4$ dichlorophenoxyacetic acid (2,4-D); (3) MS + $10 \mu \mathrm{M}$ kinetin; (4) MS + 2 $\mu \mathrm{M}$ 2,4-D + $10 \mu \mathrm{M}$ kinetin; (5) $\mathrm{MS}+10 \mu \mathrm{M}$ tyrosine; (6) $\mathrm{MS}+2 \mu \mathrm{M}$ 2,4-D + $10 \mu \mathrm{M}$ tyrosine. Tyrosine was used because it is a precursor for the biosynthesis of betacyanin. The cultures were maintained in a growth room (photoperiod and temperature as previously described), under two different light conditions: 1- white light (supplied by a Sylvania $20 \mathrm{~W}$, and fluorescent lamp, daylight type 20W), 2- white light plus UV-A (320-400 nm; maximum emission at $360 \mathrm{~nm}, 15 \mathrm{~W}$ ) under the same conditions as white light alone. In all treatment the fluence was $1.6 \mathrm{~W} \cdot \mathrm{m}^{-2}$.

\section{Evaluation of plant development}

The effects of each treatment were evaluated according to following criteria: 1- plant height; 2number of shoots per explant; 3- presence of roots; 4- pigment production (betacyanins and chlorophylls); 5- biomass production taking into account dry weight (DW). For dry weight determination, after eight weeks of in vitro culture, groups of 15 plantlets from each treatment were dehydrated at $37{ }^{\circ} \mathrm{C}$ for $72 \mathrm{~h}$, until their weights were constant.

\section{Quantification of pigments}

After eight weeks of in vitro culture, plants were separated in groups of 10 individuals from each treatment and lyophilized. For betacyanin extraction, the dried material was weighted and then homogenized in $80 \%$ methanol, followed by centrifugation at $1668 \mathrm{rpm}$ for $5 \mathrm{~min}$. The supernatant was collected and quantification of total betacyanins was obtained through maximum absorbance at $537 \mathrm{~nm}$ using a spectrophotometer (Spectronic Genesys 2, SERL 3N270093004). 
Betacyanin concentration was determined taking into account the molar extinction coefficient for amaranthine $\left(5.66 \times 10^{4}\right)$ (Piattelli et al., 1969). To determine total chlorophylls ( $\mathrm{a}$ and $\mathrm{b}$; $\mathrm{Chl}$ a and $\mathrm{Chl} b$ ), dried material was weighed and then macerated in dimethylsulfoxide (DMSO) at $61{ }^{\circ} \mathrm{C}$ for $12 \mathrm{~h}$. After this, the material was filtered through paper filter (Whatman No. 01). The spectrophotometrical quantification was determined through measurement of absorbance in the crude extract at wavelengths used by Soave and Silva (1993).

\section{Statistical analysis}

Data from measurements of shoot length and biomass accumulation were submitted to variance analysis (ANOVA) and Tukey test at 5\% significance level. Plantlets grown in each culture medium were compared for each light condition. Additionally, plantlets submitted to each light condition were compared when grown in each culture medium.

\section{RESULTS}

\section{Organogenesis of aerial parts}

After eight weeks in culture the treatment with kinetin + 2,4-D/ white light + UV-A and tyrosine + 2,4-D/ white light were not able to initiate shoot development (Table 1). The development of 3 or 4 shoots per explant was observed only in the presence of kinetin, independent of the incident light. Treatment with kinetin also led to significant increase in development of total shoots, mainly when the culture was maintained under white light. Higher regeneration frequency (RF) of 3 shoots/ plantlet $(41.7 \%)$ was observed in media containing this growth regulator and under white light (Table 1). These shoots resulted from multiple shooting produced by axillary buds. For treatments with tyrosine under white light or white light + UV-A, and treatment with MS under white light + UV-A, the RF of 1 shoot/ plantlet was similar corresponding, respectively, to $95 \%, 95.8 \%$ and $96 \%$. These results were higher than the controls (MS/ white light) $(\mathrm{RF}=76 \%)$ (Table 1$)$.

The effect of 2,4-D on the development resulted primarily on callus formation. Only treatments with 2,4-D + kinetin / white light and 2,4-D + tyrosine / white light + UV-A resulted in development of new shoots.

\section{Growth of shoots and rhizogenesis}

All plantlets regenerated in MS and MS + tyrosine medium developed roots under either light quality tested. Low percentage of root formation was obtained only in medium containing 2,4-D (Table 1). After eight weeks plantlets developed in MS and MS + tyrosine under white light were the highest ones: $7.40 \mathrm{~cm}$ and $7.05 \mathrm{~cm}$ height respectively (Fig. 1 ). The addition of 2,4-D to culture medium inhibited the growth of plantlets, resulting in average length of $0.72 \mathrm{~cm}$ and $1.11 \mathrm{~cm}$ in $\mathrm{MS}+$ kinetin + 2,4-D and MS + tyrosine + 2,4-D, respectively (Fig. 1).

Table 1 - Effect of different treatments on in vitro development of A. brasiliana after 8 weeks

\begin{tabular}{|c|c|c|c|c|c|c|}
\hline \multicolumn{2}{|c|}{ Treatments } & \multicolumn{5}{|c|}{ Parameters } \\
\hline \multirow{2}{*}{ Media } & \multirow{2}{*}{ Ilumination } & \multicolumn{4}{|c|}{ Regeneration frequency $(\mathrm{RF} \%)$} & \multirow{2}{*}{ Rooting (\%) } \\
\hline & & $1 S * *$ & $2 S$ & $3 S$ & $4 S$ & \\
\hline \multirow{2}{*}{ MS } & White light & 76 & 24 & 0 & 0 & 96 \\
\hline & White light + UV-A & $96^{\mathrm{a}}$ & $4^{\mathrm{a}}$ & 0 & 0 & 100 \\
\hline \multirow{2}{*}{$\mathrm{MS}+10 \mu \mathrm{M}$ kinetin } & White light & $4^{\mathrm{a}}$ & 24.3 & $41.7^{\mathrm{a}}$ & $30^{\mathrm{a}}$ & 80 \\
\hline & White light + UV-A & $44^{\mathrm{a}}$ & 32 & $16^{\mathrm{a}}$ & 8 & $76^{\mathrm{a}}$ \\
\hline \multirow{2}{*}{$\begin{array}{c}\mathrm{MS}+10 \mu \mathrm{M} \text { kinetin }+2 \\
\mu \mathrm{M} 2,4-\mathrm{D}\end{array}$} & White light & 86 & 14 & 0 & 0 & $4^{\mathrm{a}}$ \\
\hline & White light + UV-A & $*$ & $*$ & $*$ & $*$ & $*$ \\
\hline \multirow{2}{*}{$\mathrm{MS}+10 \mu \mathrm{M}$ tyrosine } & White light & $95^{\mathrm{a}}$ & $5^{\mathrm{a}}$ & 0 & 0 & 100 \\
\hline & White light + UV-A & $95.8^{\mathrm{a}}$ & $4.2^{\mathrm{a}}$ & 0 & 0 & 100 \\
\hline \multirow{2}{*}{$\begin{array}{c}\mathrm{MS}+10 \mu \mathrm{M} \text { tyrosine }+2 \\
\mu \mathrm{M} 2,4-\mathrm{D}\end{array}$} & White light & $*$ & $*$ & $*$ & $*$ & $*$ \\
\hline & White light + UV-A & 94 & 6 & 0 & 0 & $8^{a}$ \\
\hline
\end{tabular}

*Treatments resulting in no shoot development. ** $1 \mathrm{~S}, 2 \mathrm{~S}, 3 \mathrm{~S}, 4 \mathrm{~S}$ - number of shoot developed/explant. Letter indicate results that are significantly different from control conditions (MS with white ligth) at $p=0.05$ level. 


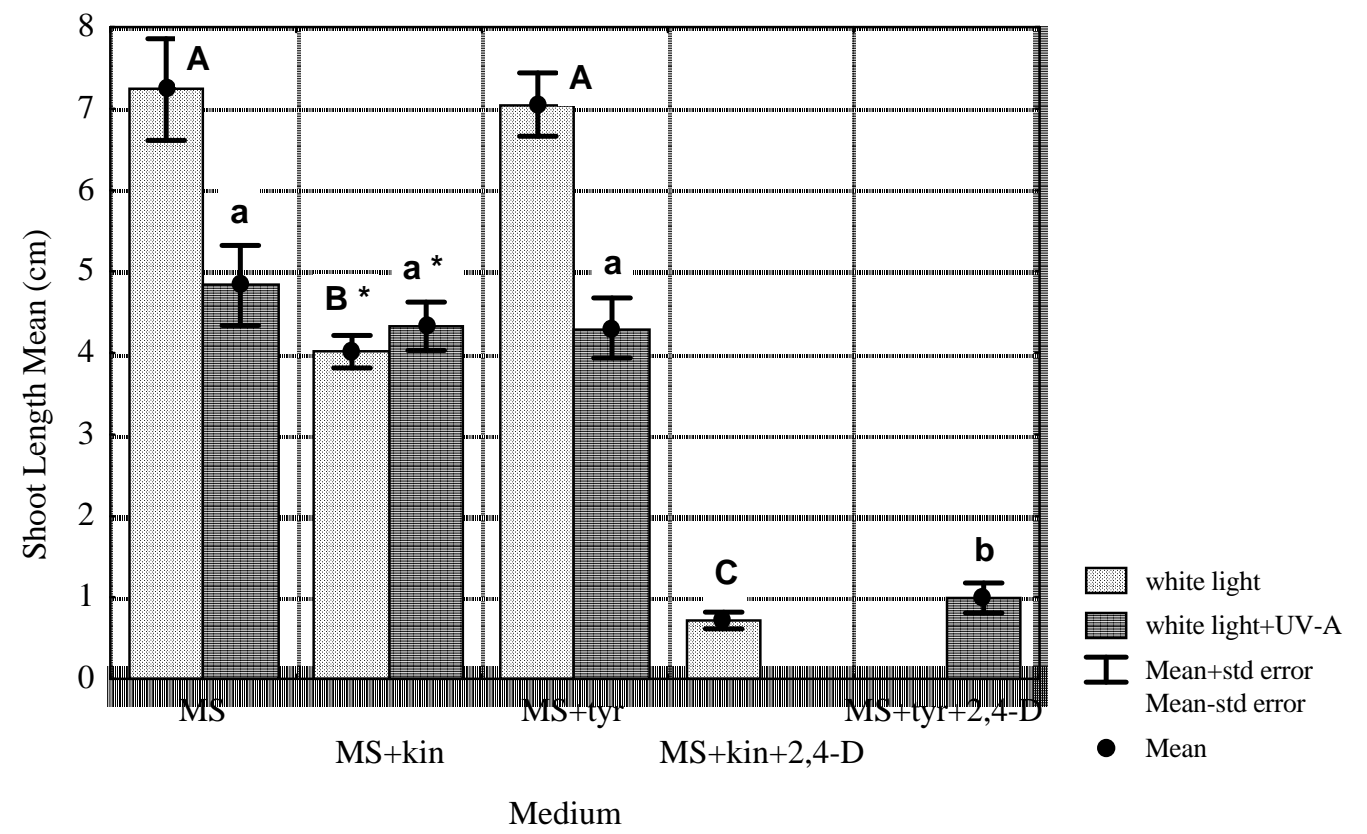

Figure 1 - Shoot lengths after 8 weeks of in vitro culture. Different letters indicate results that are significantly different at $p=0.05$ level. Small caps refer to the analyses of plantlets submitted to white light while capital letters refer to plantlets submitted to UV-A. Stars indicate equal results for plantlets cultivated in the same media culture (kin - kinetin; tyr - tyrosine).

\section{Production of biomass and pigments}

Plantlets grown in MS and in MS plus kinetin, both under white light, presented the highest biomass production, as evaluated by dry weight accumulation (Fig. 2).

The medium with tyrosine led to lowest values of biomass production independent of light treatment.

The highest production of betacyanins $(0.30$ $\mu$ mol betacyanin $\mathrm{g}^{-1}$ dry weight) was found for plantlets grown with kinetin/white light, which corresponded to an increase of 1.7 fold over that for plants grown in MS under the same kind of illumination (Table 2).

Yet for kinetin medium, plantlets grown under white light + UV-A presented 1.2 fold higher betacyanin production compared to MS medium under the same illumination. A similar increase was attained by plantlets treated with tyrosine/ white light (Table 2)Plantlets grown in MS, MS + kinetin and MS + tyrosine media, illuminated with white light, presented the highest chlorophyll production: $3.88 ; 3.57$ and $3.79 \mathrm{Chl}$ a/ Chl b g ${ }^{-1}$ dry weight. The lowest value was observed in plantlets developed with 2,4-D + kinetin under white light. Plantlets grown in MS and $\mathrm{MS}+$ tyrosine and under white light + UV-A showed the lowest values for $\mathrm{Chl} \mathrm{a} / \mathrm{Chl} \mathrm{b}$ ratio when compared with the results obtained for the same medium under white light alone (Table 2). 


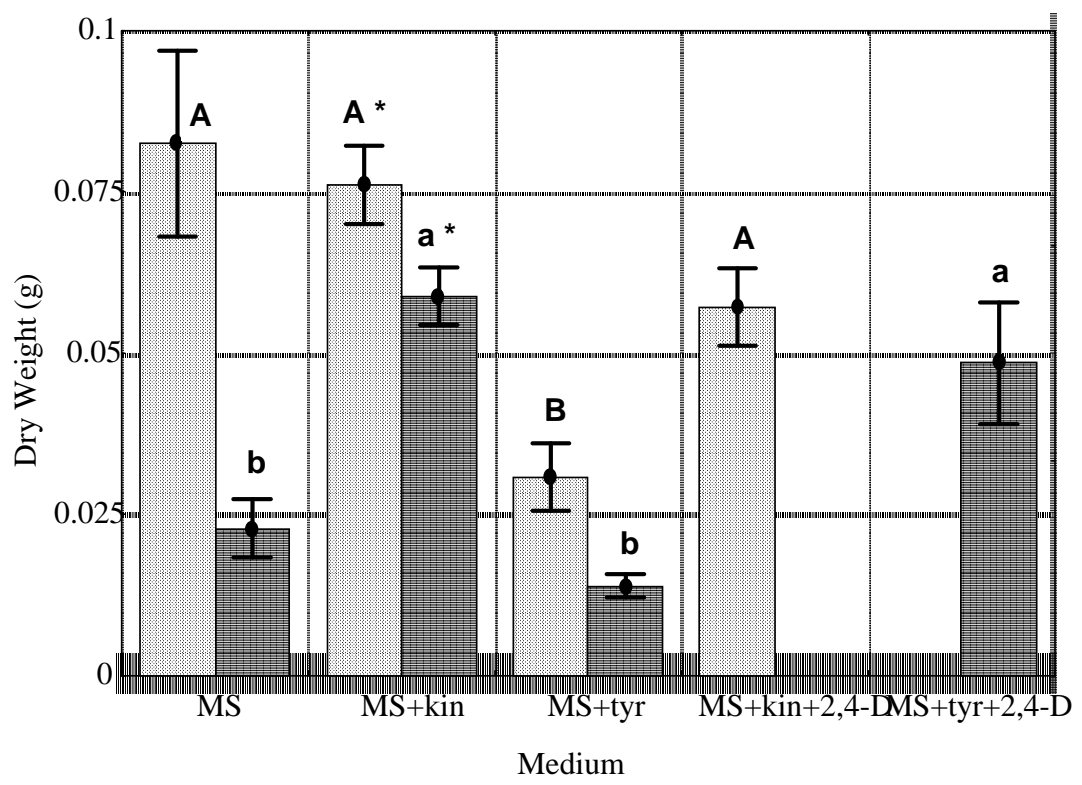

Figure 2 - Accumulation of biomass by plantlets of A. brasiliana. Different letters indicate results that are significantly different at $p=0.05$ level Small caps refer to the analyses of plantlets submitted to white light while capital letters refer to plantlets submitted to UV-A. Stars indicate equal results for plantlets cultivated in the same media culture.

$\underline{\text { Table } 2 \text { - Pigments content in plantlets of A. brasiliana from different in vitro culture conditions. }}$

\begin{tabular}{|c|c|c|c|}
\hline \multicolumn{4}{|c|}{ Pigments content } \\
\hline Culture Media & Illumination & Chl a / Chl b ratio & $\begin{array}{c}\text { Betacyanin } \\
\text { accumulation } \mu \text { mol. } g^{-1} \\
(D W) \pm S D\end{array}$ \\
\hline MS & White light & 3.88 & $0.17 \pm 0.01$ \\
\hline & White light + UV-A & 2.99 & $0.100 \pm 0.001$ \\
\hline $\mathrm{MS}+10 \mu \mathrm{M}$ kinetin & White light & 3.57 & $0.30 \pm 0.12$ \\
\hline & White light + UV-A & 3.40 & $0.20 \pm 0.02$ \\
\hline $\begin{array}{c}\mathrm{MS}+10 \mu \mathrm{M} \text { kinetin }+2 \mu \mathrm{M} \\
2 \text {.4-D }\end{array}$ & White light & 0.30 & $0.020 \pm 0.003$ \\
\hline $\mathrm{MS}+10 \mu \mathrm{M}$ tyrosine & White light & 3.79 & $0.21 \pm 0.08$ \\
\hline & White light + UV-A & 2.11 & $0.13 \pm 0.01$ \\
\hline $\begin{array}{c}\mathrm{MS}+10 \mu \mathrm{M} \text { tyrosine }+2 \mu \mathrm{M} \\
2,4-\mathrm{D}\end{array}$ & White light + UV-A & 1.13 & $0.050 \pm 0.003$ \\
\hline
\end{tabular}




\section{DISCUSSION}

Addition of kinetin to culture medium induced formation of 3 or 4 shoots/ explant, while other treatments did not result in such elevated regeneration rates. It could be possible to suppose an antagonic effect of exogenous cytokinin and endogenous auxin (Taiz and Zeiger, 2003). The combination MS + white light produced plantlets at a significantly higher rate than the other treatments tested, except for tyrosine + white light. UV-A light contributed to a significant shortening of shoots, unless kinetin was present in the medium. According to Hopkins (1995), simultaneous irradiation with UV-A and white light led to stem growth inhibition when compared with control plants grown under white light alone. Specific information about signal transduction for UVstimulations in plants is infrequent. The responses could result from direct damage to essential components or from UV absorption by specific photoreceptors or growth regulators (Ballaré et al., 1995). Many important plant developmental responses are related to Blue-UVA light photoreceptor, the cryptocrome (Lin, 2000), and the shortening of shoots observed in this work could be consequence of cryptocrome activation by UV-A. The phytocrome A might also have a role in UV-A plant response (Chun et al., 2001), and its participation in this case could not be discharged. Plantlets developed in tyrosine/ white light also presented a prominent shoot growth which could be attributed to tyrosine aminoacid integration in primary metabolism of plantlets, favoring responses linked to morphogenesis.

The presence of both kinetin or auxin in all media resulted in smaller rooting. It is known that exogenous application of cytokinins inhibits primary growth of roots, and this inhibition depends on exposition to auxins (Cary et al., 1995; Gürel and Wren, 1995). The highest biomass accumulation occurred in MS, MS + kinetin and MS + kinetin + 2,4-D media, all of them under white light (Fig. 2). However, biomass accumulation for the latter was mainly related to callus formation instead of shoot regeneration. There were no differences in biomass accumulation between plantlets grown with kinetin under white or UV-A light. The same result was observed in bean cultures cultivated under UV-A or white light by Antonelli et al. (1997).

Kinetin / white light treatment stimulated a higher production of betacyanin. This result was in agreement with Bamberger and Mayer (1960), who reported increased pigment synthesis in plantlets of Amaranthus caudatus in presence of kinetin. It has been demonstrated that betacyanin biosynthesis is also stimulated by white light in Amaranthus tricolor and Chenopodium rubrum (Berlin et al., 1986). Plantlets of A. brasiliana grown in MS with kinetin under white or white + UV-A illumination or MS plus tyrosine under white light, produced more betacyanin than other treatments (Table 2). Other authors (Bianco Colomas and Hugues, 1990; Rudat and Göring, 1995) have already described positive effects of kinetin on betacyanin synthesis for both white light and UV-A .

UV-B radiation frequently alters pigments concentration as, for instance, chlorophylls (Day and Demchik, 1996) and also modifies plant development due to its deleterious effects on chromophores associated to photosynthesis (Caldwell et al., 1995). In MS, MS + kinetin and $\mathrm{MS}+$ tyrosine media, the $\mathrm{Chl} \mathrm{a} / \mathrm{Chl} \mathrm{b}$ ratio decreased after inclusion of additional UV-A (Table 2). Illumination with UV-B caused reduction of chlorophylls content in many species mainly due to membrane disruption in chloroplasts and destruction of chlorophylls (Sato et al., 1994; Singh, 1994).

The results showed that among the investigated possibilities, the combination of kinetin/ white light was the best protocol for in vitro micropropagation of $A$. brasiliana. Under such conditions, it provided higher regeneration frequency of 4 shoots/ explant and $80 \%$ rooting, but also the highest betacyanins synthesis. For $A$. brasiliana, the use of UV-A did not increase betacyanins production and decreased biomass accumulation and Chlorophyll a/ Chlorophyll b ratio, and, in to most treatments, resulted a reduced frequency of shoot regeneration. 


\section{ACKNOWLEDGMENTS}

This work was supported by $\mathrm{CNPq}$ and Fundação Universitária José Bonifácio.

\section{RESUMO}

Culturas de tecidos de Alternanthera brasiliana (L.) Kuntze foram tratadas com diferentes reguladores de crescimento (Cinetina e 2,4-D), tirosina e com ultravioleta longo (UV-A; 320 $400 \mathrm{~nm}$ ) adicional com o intuito de observar seus efeitos no desenvolvimento e produção de pigmentos. Segmentos nodais de plantas crescidas a partir de sementes foram inoculados nos meios de cultura testados e mantidos sob os diferentes tipos de iluminação. Após 8 semanas este material foi utilizado para avaliação da produção de biomassa, clorofilas e betacianinas. O meio de Murashige and Skoog (MS) + cinetina proporcionou plântulas com até 4 brotos/explante. Este meio iluminado com luz branca (tipo luz do dia) foi a combinação mais adequada para micropropagação, pois apresenta maior porcentagem de enraizamento e maior produção de betacianinas. Plântulas crescidas sob iluminação com ultravioleta adicional tiveram diminuídas tanto a produção de biomassa quanto a relação Clor a/ Clor b. A adição de 2,4$\mathrm{D}$ ao meio de cultura resultou na inibição da produção de pigmentos e no crescimento das plântulas.

\section{REFERENCES}

Antonelli, F.; Grifoni, D.; Sabatini, F. and Zipoli, G. (1997), Morphological and physiological responses of bean plants to supplemental UV radiation in a Mediterranean climate. Plant Ecol., 128, 127-136.

Ballaré, C. L.; Barnes, P. W. and Flint, S. D. (1995), Inhibition of hypocotyl elongation by ultraviolet $\mathrm{B}$ radiation in de-etiolating tomato seedlings. I. The photoreceptor. Physiol. Plant., 93 : (4), 584 592.

Bamberger, E. and Mayer, A. M. (1960), Effect of kinetin on formation of red pigment in seedlings of Amaranthus retroflexus. Science, 131, 1094-1095.

Berlin, J.; Sieg, S.; Strack, D.; Bokern, M. and Harms, H. (1986), Production of betalains by suspension cultures of Chenopodium rubrum L. Plant Cell Tiss. Org. Cult., 5, 163-174.

Bianco-Colomas, J. and Hugues, M. (1990), Establishment and characterization of betacyanin producing cell line of Amaranthus tricolor: inductive effects of light and cytokinin. J. Plan. Physiol., 136, 734-739.

Caldwell, M. M.; Teramura, A. H.; Tevini, M; Bornman, J. F.; Björn, L. O. and Kulandalvelu, G. (1995), Effects of increased solar ultraviolet radiation on terrestrial plants. Ambio, 24, 166-173.

Cary, A.J.; Liu, W. and Howell, S. H. (1995), Cytokinin action is coupled to ethylene in effects on the inhibition of root and hypocotyl elongation in Arabdopsis thaliana seedlings. Plant Physiol., 107, 1075-1082.

Chun, L.; Kawakami, A. and Christopher, D. A. (2001), Phytochrome A mediates blue light and UV-A-dependent chloroplast gene transcription in green leaves. Plant Physiol., 125 : (4), 1957-1966.

Day, T. A. and Demchik, S. M. (1996), Influence of enhanced UV-B radiation on biomass allocation and pigment concentrations in leaves and reproductive structures of greenhouse-growth Brassica rapa. Vegetatio, 127, 109 - 116.

Gürel, E. and Wren, M. J. (1995), In vitro development from leaf explants of sugar beet (Beta vulgaris L.). Rhizogenesis and the effects of sequential exposure to auxin and cytokinin. Ann. Bot., 75, 31-38.

Holm-Hansen, O.; Helbling, E. and Lubin, D. (1993), Ultraviolet radiation in Antarctic inhibition of primary production. Photochem. Photobiol., 58, 567 - 570.

Hopkins, W. G. (1995), Introduction to plant physiology. John Wiley and Sons Inc.

Lagrota, M. M. C.; Wigg, M. D.; Santos, M. M. G.; Miranda, M. M. F. S.; Camara, F. P.; Conceiro, J. N. S. S. and Costa, S. S. (1994), Inhibitory activity of extracts of Alternanthera brasiliana (Amaranthaceae) against the Herpes Simplex Virus. Phytotherapy Res., 8, 358-361.

Lin, C. T. (2000) Blue light plant receptors. Trends in Plant Sci., 5 : (8), 337-342.

Mabry, T. J. (1980), Betalains. In: Bell, E. A. and Harlwood, B. V. (Eds.). Encyclopedia of Plant Physiology. Secondary products. Berlin: Springer Verlag. (New series, 8). pp. 513-533.

Macedo, A. F.; Barboza, N. C.; Esquibel, M. A.; Souza, M. M. and Cechinel-Filho, V. (1999), Pharmacological and phytochemical studies of callus extracts from Alternanthera brasiliana. Die Pharmazie, 54, 776-777. 
Murashige, T. and Skoog, F. (1962), A revised medium for rapid growth and bioassays with tobacco tissue cultures. Physiol. Plant., 15, 473497.

Piattelli, M. and Minale, L. (1964), Pigments of Centrospermae - II. Distribution of betacyanins. Phytochem. 3, 547-557.

Piattelli, M.; Giudici, M. N. and Castrogiovanni, V. (1969). Photocontrol of amaranthin synthesis in Amaranthus tricolor. Phytochem., 8, 731-736.

Quesada. A.; Mouget, J. A. and Vincent, W. F. (1995), Growth of Antarctic cyanobacteria under ultraviolet radiation: UV-A counteracts UV-B inhibition. J. Phycol., 31, 242-248.

Rudat, A. and Göring, H. (1995), Induction of betacyanin formation in cell cultures of Chenopodium album under UV-light irradiation. J.Exp. Bot., 46, 129-134.

Sato, T.; Kang, H. and Kumagai, T. (1994), Genetic study of resistance to inhibitory effects of UV radiation in rice (Oryza sativa). Physiologia Plant., 91, 234- 238.
Si-Man, Z.; Yong-Sheng, H.; Tabba, H. D. and Smith, K. M. (1988), Inhibitor against the human immunodeficiency virus in aqueous extracts of Alternanthera philoxeroides. Chinese Med. J., 101, 816-866.

Singh, A. (1994), Effects of enhanced UV-B radiation on higher plants. Trop. Ecol., 35, 321247.

Soave, R. C. F. and Silva, O. A. (1993), Phenological aspects and content variation of chlorophylls a and b of Caryocar brasiliensis. Arq. Biol. Tecnol., 36 : (1), 57-69.

Souza, M. M.; Kern, P.; Floriani, A. E. O. and Cechinel-Filho, V. (1998), Analgesic properties of hydroalcoholic extract obtained from Alternanthera brasiliana. Phytoth. Res., 12, 279281.

Taiz, L. and Zeiger, E. (2003), Plant Physiology. $2^{\text {nd }}$ ed. USA: Sinauer Associates Inc.

Received: August 12, 2003 ; Revised: July 18, 2004; Accepted: March 08, 2005. 